Volume 8. No. 1.2, 2020

International Journal of Emerging Trends in Engineering Research

Available Online at http://www.warse.org/IJETER/static/pdf/file/ijeter3581.22020.pdf

https://doi.org/10.30534/ijeter/2020/3581.22020

\title{
Oil Palm Empty Fruit Bunch (OPEFB) Handsheet Production from Optimized Biodelignification of Rhynchophorus Ferrugineus Microbiome's Enzymes
}

\author{
Ashuvila Mohd Aripin ${ }^{1}$, Amir Hamzah Abd Rashid ${ }^{1}$, Sharfina Mutia Syarifah ${ }^{1}$, Chan Chee Ming ${ }^{2}$, Muhd \\ Hafeez Zainulabidin ${ }^{3}$, Nadiah Ishak ${ }^{4}$, Sharmiza Adnan ${ }^{5}$, Darren Lee Seng Chye ${ }^{6}$ and Angzzas Sari Mohd \\ Kassim $^{1}$ \\ ${ }^{1}$ 1Department of Chemical Engineering Technology, Faculty of Engineering Technology, Universiti Tun Hussein \\ Onn Malaysia, Campus Pagoh, 84600 Pagoh, Muar, Johor, Malaysia., angzzas@uthm.edu.my \\ ${ }^{2}$ Department of Civil Engineering Technology, Faculty of Engineering Technology, Universiti Tun Hussein Onn \\ Malaysia, Campus Pagoh, 84600 Pagoh, Muar, Johor, Malaysia. \\ ${ }^{3}$ Department of Mechanical Engineering, Faculty of Mechanical and Manufacturing Engineering, Universiti Tun \\ Hussein Onn Malaysia, 86400 Parit Raja, Johor, Malaysia. \\ ${ }^{4}$ Department of Science and Technology, Faculty of Business Innovation and Technology, Kolej Universiti Islam \\ Melaka, 78200 Kuala Sungai Baru, Melaka, Malaysia. \\ ${ }^{5}$ Pulp and Paper Programme, Forest Product Division, Forest Research Institute Malaysia (FRIM), 521109 \\ Kepong, Selangor, Malaysia \\ ${ }^{6}$ Syarikat Saintifik Bersatu, 16 Jalan Tukas, Taman Soga, 83000 Batu Pahat, Johor, Malaysia
}

\begin{abstract}
Oil palm plantation generates massive amount of oil palm empty fruit bunch (OPEFB) which source great amount of cellulose. However, wrapping this cellulose is an adhesive compound called lignin. Biodelignification process was applied to remove lignin in pulp and paper industry. Therefore, this study is focused on optimum conditions of delignification process using a combination of bacteria from Rhynchophorus ferrugineus on OPEFB. The composition of chemicals was characterized according to the TAPPI standard method and Kursher-Hoffner method. The Box-Behnken design (BBD) was used to determine the optimum conditions of delignification process based on lignin loss of OPEFB. The optimized fiber was investigated based on mechanical properties according to TAPPI standard methods. From BBD analysis, the finest conditions for delignification were recognized to be at $35^{\circ} \mathrm{C}$ in $48 \mathrm{~h}$ incubation time with $5 \mathrm{~mL}$ of $1 \%$ glucose for predicted value 54.3\% compared to experimental value $52 \%$ of lignin loss as revealed by confirmatory study. The highest result of chemical analysis was recognized at run $12(1.15 \%), 10(12.35 \%), 4(48.99 \%)$ and $5(1.28 \%)$ for extractive, lignin, cellulose and ash content respectively. The tensile, burst and tear were identified as $9.93 \mathrm{Nm} / \mathrm{g}, 0.98 \mathrm{kPa} \cdot \mathrm{m}^{2} / \mathrm{g}$ and $2.57 \mathrm{mN} . \mathrm{m}^{2} / \mathrm{g}$ respectively for handsheet product at optimum conditions. In conclusion, the results obtained was indicated that the delignification process via bacteria combination from $R$. ferrugineus is a viable alternative pulping process for pulp and paper-based industry. The delignification process on OPEFB also provides a cleaner
\end{abstract}

technology process and more sustainable development for the country.

Key words: Lignocellulosic; biodelignification; pulp and paper; lignin; Rhynchophorus ferrugineus.

\section{INTRODUCTION}

Palm oil (Elaeis guineensis) is a dominant agricultural crop in Malaysia. Over the last year, Malaysia has cultivated more than 5 million hectares of oil palm production and become one of the world largest exporters for palm oil. The Malaysia industry of oil palm had become the leading producers and exporters of palm oil, collectively generate large waste amounts of oil palm biomass. The oil palm empty fruit bunch (OPEFB) has become one of the massive waste productions with an annual value of 16 million tons [1].

The OPEFB was typically burned in palm oil mill incinerator and recycled ash content as the plantation fertilizers. However, OPEFB incineration has been discouraged due to the environmental issue [2]. The waste of lignocellulosic biomass must be used to ensure environmentally sustainable oil palm industry.

Lignocellulose biomass is the most abundant renewable biomass worldwide composed of hemicellulose, cellulose and lignin, including other minor components. Both hemicellulose and cellulose components are sugar polymers, hence potray possible source for fermentable sugars or other sugar product development. Inside the lignocellulose, lignin 
fraction acts as a blockage towards microbial and enzyme penetration. Lignin significantly reduces fermentable sugar yields and adversely affects general energy production process from biomass resources to the extent that it is uneconomical [3]. To overcome this limitation, new types of biomass treatments are required for efficient production and economical [4].

Pulping was aimed at reducing cellulose crystanillinity, increasing the total surface area of biomass, breaking the lignin seal and removing hemicellulose, thereby increasing glucose yield. There are several major processes of treatment, for example mechanical and chemical treatments. Meanwhile, the biological treatment emphasizes strategies that harness microbes' natural metabolic activity to improve the biomass cycle potential on the agricultural residues. The leading process is the traditional pulping process such as chemical and mechanical pulping process, but they require significant energy inputs and often cause pollution from their effluents [5].

Biological pulping process uses less energy and chemicals, more economical and more environmentally sustainable [6], as compared to traditional pulping process. To date, the biological pulping process employs certain microorganisms, including white-rot and brown-rot fungi to deconstruct recalcitrantcy of lignin [7]. Although the successful fungi application in the biopulping processs has been observed, however, it is sensitive towards shearing and requires long incubation time (up to 60 days) which significantly reduces the lignin content [8]. Therefore, to overcome this problem, bacteria are introduced as an agent in the delignification process of lignocellulosic material.

Therefore, in this study, the optimisation of delignification conditions by using Rhynchophorus ferrugineus microbiome's enzymes on OPEFB was explored to significantly remove the lignin content in the waste materials. Henceforth, the objectives of this study are (i) to characterize the chemical properties of OPEFB prior to, (ii) optimise bioprocessing conditions of bacterial on OPEFB using Box-Behnken design (BBD) and (iii) to produce paper handsheet and determine its mechanical properties suitable for pulp and paper production.

\section{MATERIALS AND METHOD}

\subsection{Bacteria Species}

our major gut microbiome species having the ability to degrade lignin have been isolated from $R$. ferrugineus larvae and identified as Klebsiella sp., Enterobacter sp., Serratia $s p$., and Pseudomonas sp. from previous research were used in this experiment [9]

\subsection{Preparation of OPEFB}

OPEFB was obtained from Pertubuhan Peladang Negeri Johor (PPNJ), Kahang, Kluang, Johor. Prior to use, the biomass was cleaned with tap water to remove soil and other impurities and sun dried until the water content was $10 \%$ or less. The dried sample was stored in plastic bags at room temperature.

Dried OPEFB was grounded to particle size about $0.4 \mathrm{~mm}$ and sieved through (40 mesh). Subsequently, the moisture content of powder OPEFB fiber was measured using moisture analyser [10]. If the moisture content is above $12 \%$, the powder must be dried in a circulated oven at $40{ }^{\circ} \mathrm{C}$ for 24 hours.

\subsection{Inoculum Preparation}

Isolated bacteria species of Klebsiella sp., Enterobacter sp., Serratia sp., and Pseudomonas sp. were grown and incubated on LB agar overnight at $37{ }^{\circ} \mathrm{C}$. After incubation, a single colony from every plate was transferred into LB broth media and incubated 4 to 6 hours at $37^{\circ} \mathrm{C}$. Then, each inoculated bacteria was added and mix with ratio 1:1:1:1 and incubated again in a temperature-controlled still culture incubator at 37 ${ }^{\circ} \mathrm{C}$ for 4 to 6 hours to obtain a homogenous colony forming of bacteria $\left(1 \times 10^{8} \mathrm{CFU} / \mathrm{mL}\right)$ to be used as inoculum [9].

\subsection{Optimization of Biodelignifiaction Process}

\subsubsection{Preparation of Biodelignification}

Submerged fermentation is used for biological treatment of substrate in flask. The specimens (OPEFB) were heated for sterilization in autoclave at $120 \square$ for 15 minutes. After cool it was mixed with a suspension of bacteria (LB broth) and incubated based on the experimental design as presented in Table 1. After incubation period, the samples were heated again for sterilization at $120 \square$ for 15 minutes and were collected from the flask. Then, the samples were rinsed with distilled water, dried overnight at $40 \square$ prior to chemical analysis [11].

\subsubsection{Experimental Design: Box-Behnken Design (BBD)}

OPEFB's biodelignification process was optimized using Response Surface Methodology (RSM). The influence of three independent variables, A (incubation time, h), B (temperature, ${ }^{\circ} \mathrm{C}$ ) and $\mathrm{C}$ (glucose volume, $\mathrm{mL}$ ) at three levels $(-1,0,1)$ on lignin loss were investigated using BBD and the coded and actual value of experimental design are shown in Table 1. 
Ashuvila Mohd Aripin et al., International Journal of Emerging Trends in Engineering Research, 8(1.2), 2020, 253- 263

Table 1: Independent variables and their coded and actual level

\begin{tabular}{|l|c|c|c|c|c|}
\hline \multirow{2}{*}{ Factor } & \multirow{2}{*}{ Unit } & \multirow{2}{*}{ Symbol } & \multicolumn{3}{c|}{ Coded level } \\
\cline { 4 - 6 } & & & $\mathbf{- 1}$ & $\mathbf{0}$ & $\mathbf{1}$ \\
\hline $\begin{array}{l}\text { Incubation } \\
\text { time }\end{array}$ & $\mathrm{h}$ & $\mathrm{A}$ & 48 & 108 & 168 \\
\hline $\begin{array}{l}\text { Temperatur } \\
\mathrm{e}\end{array}$ & ${ }^{\circ} \mathrm{C}$ & $\mathrm{B}$ & 25 & 30 & 35 \\
\hline $\begin{array}{l}\text { Glucose } \\
\text { volume }\end{array}$ & $\mathrm{mL}$ & $\mathrm{C}$ & 5 & 15 & 25 \\
\hline
\end{tabular}

\subsubsection{Chemical Characterization of OPEFB Fiber}

All methods used for chemical analysis of OPEFB fiber were summarized in Table 2.

\subsubsection{Handsheet Making and Mechanical Properties of Handsheet}

Table 3 presents all standards for handsheet making and mechanical testing of handsheet from OPEFB.

Table 2: Method for chemical analysis of OPEFB fiber

\begin{tabular}{|l|l|c|}
\hline \multicolumn{1}{|c|}{$\begin{array}{c}\text { Chemical } \\
\text { Content } \\
\text { Analysis }\end{array}$} & \multicolumn{1}{|c|}{ Standard Method } & References \\
\hline Extractives & $\begin{array}{l}\text { Wood preparation for } \\
\text { analysis of chemical }\end{array}$ & {$[12]$} \\
\hline Holocellulose & Chlorite method & {$[13]$} \\
\hline Cellulose & $\begin{array}{l}\text { Kurscher-Hoffner } \\
\text { method }\end{array}$ & {$[14]$} \\
\hline Hemicellulose & Chlorite method & {$[13]$} \\
\hline Lignin & $\begin{array}{l}\text { Lignin acid-insoluble } \\
\text { in wood and pulp }\end{array}$ & {$[15]$} \\
\hline Ash content & $\begin{array}{l}\text { Ash in wood, pulp, } \\
\text { paper and paperboard: } \\
\text { combustion at 525 }{ }^{\circ} \mathrm{C}\end{array}$ \\
\hline
\end{tabular}

Table 3: Methods for handsheet making and mechanical testing

\begin{tabular}{|l|l|c|}
\hline $\begin{array}{l}\text { Handsheet } \\
\text { making and } \\
\text { mechanical } \\
\text { testing }\end{array}$ & Standards Method & References \\
\hline $\begin{array}{l}\text { Handsheet } \\
\text { Making }\end{array}$ & $\begin{array}{l}\text { Handsheets formation } \\
\text { for pulp physical tests }\end{array}$ & {$[17]$} \\
\hline $\begin{array}{l}\text { Preparation } \\
\text { of specimen }\end{array}$ & $\begin{array}{l}\text { Pulp handsheets } \\
\text { physical testing }\end{array}$ & {$[18]$} \\
\hline $\begin{array}{l}\text { Tensile } \\
\text { strength }\end{array}$ & $\begin{array}{l}\text { Tensile properties of } \\
\text { paper and paperboard } \\
\text { (using constant rate of } \\
\text { elongation apparatus) }\end{array}$ & {$[19]$} \\
\hline $\begin{array}{l}\text { Tearing } \\
\text { resistance }\end{array}$ & $\begin{array}{l}\text { Internal tearing } \\
\text { resistance of paper } \\
\text { (Elmendorf-type } \\
\text { method) }\end{array}$ & {$[20]$} \\
\hline $\begin{array}{l}\text { Bursting } \\
\text { resistance }\end{array}$ & $\begin{array}{l}\text { Bursting strength of } \\
\text { paper }\end{array}$ & {$[21]$} \\
\hline
\end{tabular}

\section{RESULTS AND DISCUSSIONS}

\subsection{Chemical Characterization of OPEFB Fiber}

Table 4 presents the summary of chemical compositions for OPEFB fibre before and after treatment with different conditions (incubation time, temperature and $1 \%$ glucose) under BBD.

The chemical compositions of OPEFB before treatment are extractive content $(3.60 \pm 0.14 \%)$, lignin content $(18.90 \pm$ $0.85 \%)$, holocellulose content $(77.53 \pm 0.18 \%)$, cellulose content $(42.46 \pm 0.19 \%)$, hemicellulose content $(34.58 \pm$ $0.33 \%)$ and ash content $(2.02 \pm 0.08)$. Whereas the best chemical compositions of treated OPEFB were obtained in different run such as extractive content $(1.15 \pm 0.14 \%$, Run 12), lignin content $(12.35 \pm 0.35 \%$, Run 10), hocellulose content (86.55 $\pm 0.21 \%$, Run 9), cellulose content (48.99 \pm $0.13 \%$, Run 9), hemicellulose content (37.38 $\pm 0.32 \%$, Run 9) and ash content (1.28 $\pm 0.11 \%$, Run 5).

Generally, cellulose is significant suitable parameter for the material measurement for pulp and paper production [22]. However, the high lignin content in the material can decrease the performance of the pulp and paper product that caused the paper products to yellow [23]. Therefore, Run 10 is the best conditions for chemical compositions of OPEFB as shown in Table 4.

Table 5 illustrates the chemical composition of OPEFB with other non-wood, hardwood, softwood and annual plants, which have been successfully used in pulp and paper-based industry. The cellulose content of OPEFB (47.98\%) was high and comparable with canola straw (42\%), rice straw (41.20\%), C. orientalis $(40.10 \%)$ and C. tataria $(40.30 \%)$ as shown in Table 5. In addition, the cellulose content above $40 \%$ was obtained in range of hardwood, softwood and annual plants, used to produce high quality of pulp and paper [24], [25]. According to Bidin et al. [25], the amount of cellulose influences paper strength and makes the fiber strands vulnerable to natural and synthetic dye binding.

Table 5 illustrates the chemical composition of OPEFB with other non-wood, hardwood, softwood and annual plants, which have been successfully used in pulp and paper-based industry. The cellulose content of OPEFB (47.98\%) was high and comparable with canola straw (42\%), rice straw (41.20\%), C. orientalis $(40.10 \%)$ and C. tataria $(40.30 \%)$ as shown in Table 5. In addition, the cellulose content above $40 \%$ was obtained in range of hardwood, softwood and annual plants, used to produce high quality of pulp and paper [24], [25]. According to Bidin et al. [25], the amount of cellulose influences paper strength and makes the fiber strands vulnerable to natural and synthetic dye binding. 


\subsection{Optimization of the Biodelignification Process}

A study of biodelignification process from $R$. ferrugineus microbiome's enzymes was evaluated by using RSM. The BBD was used in this study for the optimisation of delignification process by $R$. ferrugineus microbiome's enzymes on OPEFB. The effect of three independent variables such as incubation time (A), temperature (B) and $1 \%$ glucose volume $(\mathrm{C})$ were investigated as shown in Table 6. Overall, 15 experimental runs with 3 replicates were performed on the experimental results value and predicted value by the model presented in Table 6.

The highest lignin loss was observed in Run 11 with average lignin loss of 52\% with the conditions of $108 \mathrm{~h}$ incubation time, $35{ }^{\circ} \mathrm{C}$ temperature and $5 \mathrm{~mL} 1 \%$ glucose volume. Meanwhile, the lowest percentage of lignin loss was found in Run 4 with average of $29.7 \%$ at $48 \mathrm{~h}$ of: incubation time, $30^{\circ} \mathrm{C}$ temperature in $5 \mathrm{~mL}$ of $1 \%$ glucose volume. 
Table 4: Chemical compositions of OPEFB fiber

\begin{tabular}{|c|c|c|c|c|c|c|}
\hline $\begin{array}{c}\text { Sample } \\
\text { conditions }\end{array}$ & $\begin{array}{c}\text { Extractive } \\
(\boldsymbol{\%})\end{array}$ & $\begin{array}{c}\text { Lignin content } \\
(\boldsymbol{\%})\end{array}$ & $\begin{array}{c}\text { Holocellulose } \\
\text { content }(\boldsymbol{\%})\end{array}$ & $\begin{array}{c}\text { Cellulose } \\
\text { content }(\boldsymbol{\%})\end{array}$ & $\begin{array}{c}\text { Hemicellulose } \\
\text { content }(\boldsymbol{\%})\end{array}$ & $\begin{array}{c}\text { Ash content } \\
(\boldsymbol{\%})\end{array}$ \\
\hline Before Treatment & $3.60 \pm 0.14$ & $18.90 \pm 0.85$ & $77.53 \pm 0.18$ & $42.46 \pm 0.19$ & $34.58 \pm 0.33$ & $2.02 \pm 0.08$ \\
\hline 1 & $1.58 \pm 0.04$ & $15.10 \pm 0.28$ & $81.50 \pm 0.75$ & $45.77 \pm 0.41$ & $35.94 \pm 0.68$ & $1.41 \pm 0.14$ \\
\hline 2 & $2.58 \pm 0.11$ & $13.95 \pm 0.07$ & $81.80 \pm 0.14$ & $45.95 \pm 0.64$ & $35.50 \pm 0.00$ & $1.71 \pm 0.34$ \\
\hline 3 & $2.18 \pm 004$ & $13.45 \pm 0.07$ & $78.55 \pm 0.35$ & $47.90 \pm 0.28$ & $30.40 \pm 0.28$ & $1.31 \pm 0.30$ \\
\hline 4 & $2.45 \pm 0.04$ & $18.40 \pm 0.42$ & $79.30 \pm 0.07$ & $48.99 \pm 0.13 *$ & $30.71 \pm 0.76$ & $1.53 \pm 0.23$ \\
\hline 5 & $1.78 \pm 0.04$ & $14.50 \pm 0.07$ & $78.08 \pm 0.81$ & $47.33 \pm 0.64$ & $30.67 \pm 0.11$ & $1.28 \pm 0.11 *$ \\
\hline 6 & $1.58 \pm 0.04$ & $15.65 \pm 0.07$ & $81.50 \pm 0.42$ & $46.65 \pm 0.35$ & $35.30 \pm 0.71$ & $1.55 \pm 0.02$ \\
\hline 7 & $2.73 \pm 0.11$ & $15.95 \pm 0.21$ & $79.45 \pm 0.07$ & $46.81 \pm 0.78$ & $33.28 \pm 0.05$ & $1.74 \pm 0.08$ \\
\hline 8 & $2.88 \pm 0.04$ & $13.75 \pm 0.21$ & $78.75 \pm 0.42$ & $47.27 \pm 0.80$ & $31.29 \pm 0.09$ & $2.27 \pm 0.97$ \\
\hline 9 & $1.43 \pm 0.04$ & $16.95 \pm 0.07$ & $86.55 \pm 0.21 *$ & $48.53 \pm 0.81$ & $37.38 \pm 0.32 *$ & $1.61 \pm 0.11$ \\
\hline 10 & $1.85 \pm 0.14$ & $12.35 \pm 0.35 *$ & $78.88 \pm 0.04$ & $47.98 \pm 0.46$ & $31.62 \pm 0.52$ & $1.65 \pm 0.12$ \\
\hline 11 & $3.33 \pm 0.32$ & $13.85 \pm 0.07$ & $75.10 \pm 0.85$ & $48.33 \pm 1.56$ & $26.15 \pm 3.29$ & $1.67 \pm 0.05$ \\
\hline 12 & $1.15 \pm 0.14 *$ & $15.20 \pm 0.14$ & $78.83 \pm 0.25$ & $48.90 \pm 0.67$ & $30.40 \pm 0.42$ & $1.74 \pm 0.04$ \\
\hline 13 & $2.38 \pm 0.04$ & $15.15 \pm 0.07$ & $82.60 \pm 0.35$ & $48.43 \pm 0.78$ & $34.94 \pm 0.66$ & $1.87 \pm 0.04$ \\
\hline
\end{tabular}

*best values for pulp and paper based parameters

Table 5: Chemical compositions of OPEFB and other published non-wood, hardwood, softwood and annual plants

\begin{tabular}{|c|c|c|c|c|c|c|}
\hline \multirow[b]{2}{*}{ Materials } & \multicolumn{5}{|c|}{ Chemical compositions, \% } & \multirow[b]{2}{*}{ References } \\
\hline & Cellulose & Hemicellulose & Lignin & $\begin{array}{c}\text { Extractiv } \\
\text { e }\end{array}$ & Ash & \\
\hline OPEFB & $47.98 *$ & $31.62 *$ & $12.35^{*}$ & $1.85^{*}$ & 1.65 & This study \\
\hline Canola stalk & 42 & 31.6 & 17.3 & 8.2 & 2.5 & {$[26]$} \\
\hline Rice straw & 41.2 & 19.5 & 18.1 & 9.2 & $0.56 *$ & [27] \\
\hline C. orientalis & 40.1 & 30.4 & 24.5 & 6.26 & 7.83 & \multirow{2}{*}[28]{} \\
\hline C. tataria & 40.3 & 29.7 & 20.59 & 5.04 & 9.31 & \\
\hline Hardwoods & $38-55$ & $\mathrm{n} / \mathrm{a}$ & $18-26$ & 1-Jun & $0.2-0.7$ & \multirow{3}{*}[29]{} \\
\hline Softwoods & $55-61$ & $\mathrm{n} / \mathrm{a}$ & $25-32$ & 1-Jun & $0.2-0.7$ & \\
\hline Annual plants & $40-52$ & $35-47$ & $15-19$ & 5-Sep & 2-Jul & \\
\hline
\end{tabular}

$\mathrm{n} / \mathrm{a}=$ not available; $*$ best values for pulp and paper-based parameters 
To validate the statistical results and the model equation, analysis of variance (ANOVA) was performed as shown in Table 7. Moreover, the result of the degree of freedom (DF) is 9 which is equivalent to the independent observation number. The $p$ value can be taken as factor for significant verification of each coefficient which explains the interaction between the strength of each parameter and mutual interaction pattern between variables [30]. Several criteria were used to check goodness of fit of the model. The $p$-value less than 0.05 shows that the model term are significant as shown in Table 7. In this case, $\mathrm{B}, \mathrm{C}, \mathrm{A}^{2}, \mathrm{C}^{2}, \mathrm{AB}, \mathrm{AC}$ and $\mathrm{BC}$ had a significant effect ( $p<0.05$ ) on lignin loss of OPEFB. Lack of fit $F$ value 48.22 implies that the lack of fit is significant. The terms A and $\mathrm{B}^{2}$ seems to be insignificant, which can be neglected from the model without affecting goodness of the fit [31].

Table 8 illustrates the ANOVA for regression quadratic model analysis by BBD. The determination coefficient $\left(\mathrm{R}^{2}\right)$ value 0.9372 indicates that the model was able to explain $93.72 \%$ of the variability in the response. In addition, the value of $\mathrm{R}^{2}$ also is presented a correlation between the predicted and the experimental values [30], [31]. Also the adjusted determination coefficient $\left(\right.$ adj. $\left.\mathrm{R}^{2}=0.9210\right)$ was high, indicating the significancy of the model [31].

Table 8: ANOVA for the regression model

\begin{tabular}{|c|c|}
\hline Source & Value \\
\hline Standard deviation & 1.8 \\
\hline $\mathrm{R}^{2}$ & 0.9372 \\
\hline Adjusted $\mathrm{R}^{2}$ & 0.921 \\
\hline Predicted $\mathrm{R}^{2}$ & 0.8895 \\
\hline
\end{tabular}

The determination of high lignin loss with optimal levels of incubation time (A), temperature (B) and $1 \%$ glucose (C) was inferred with second-order polynomial model for evaluating the relationship between dependent and independent variables. The following second-order polynomial equation based on the multiple regression analysis explained between variables and lignin loss OPEFB:

Lignin loss $\%=38.0333+1.2454 \mathrm{~B}+0.9714 \mathrm{C}-4.0500^{2}+$

$$
2.85383^{2}-3.600 \mathrm{AB}+6.0971 \mathrm{AC}-7.917 \mathrm{BC}
$$

where $\mathrm{A}, \mathrm{B}$ and $\mathrm{C}$ are the independent variables.

To gain a better understanding of the effects of the variables on the loss of lignin, the predicted model has been presented as a plot of the response surface.

\subsection{Incubation Time vs. Temperature}

Figure 1 illustrates the interaction between incubation time, temperature and their reciprocal interactions with the lignin loss percentage from the delignification process. This response surface plot was generated holding at $1 \%$ glucose volume. As shown in Figure 1, both the incubation time and temperature had positive impact on the delignification process. An increase of the lignin loss can be observed with the reduction of incubation time and the increases of temperature applied to OPEFB delignification.

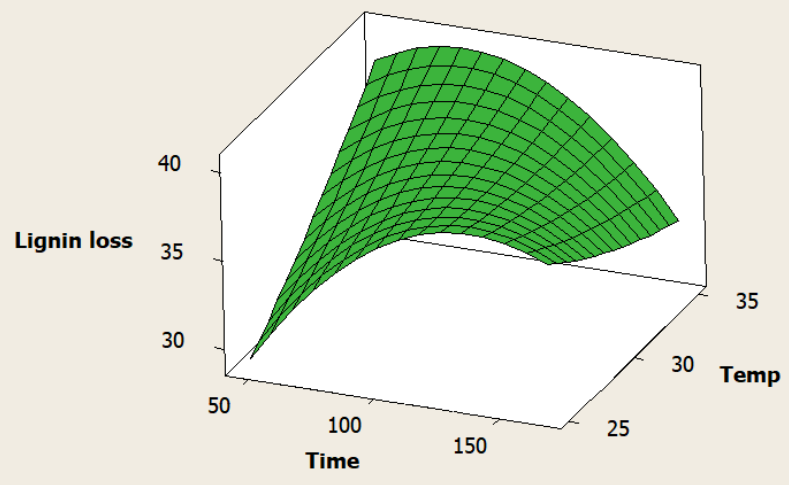

Figure 1: Response surface plot for the interaction between incubation time and temperature on lignin loss (hold values: $1 \%$ glucose volume, $15 \mathrm{~mL}$ )

\subsection{Incubation Time vs. 1\% Glucose Volume}

Figure 2 shows the interaction between incubation time and $1 \%$ glucose volume with temperature at $30^{\circ} \mathrm{C}$. As shown in Figure 2, both the incubation time and $1 \%$ glucose volume have synergistic effect on the delignification process. An increase of the lignin loss can be observed with the increases of incubation time and $1 \%$ glucose volume applied to OPEFB fibre delignification. In addition, the low lignin loss was obtained at high incubation time (168 h) and low $1 \%$ glucose volume (5 $\mathrm{mL})$.

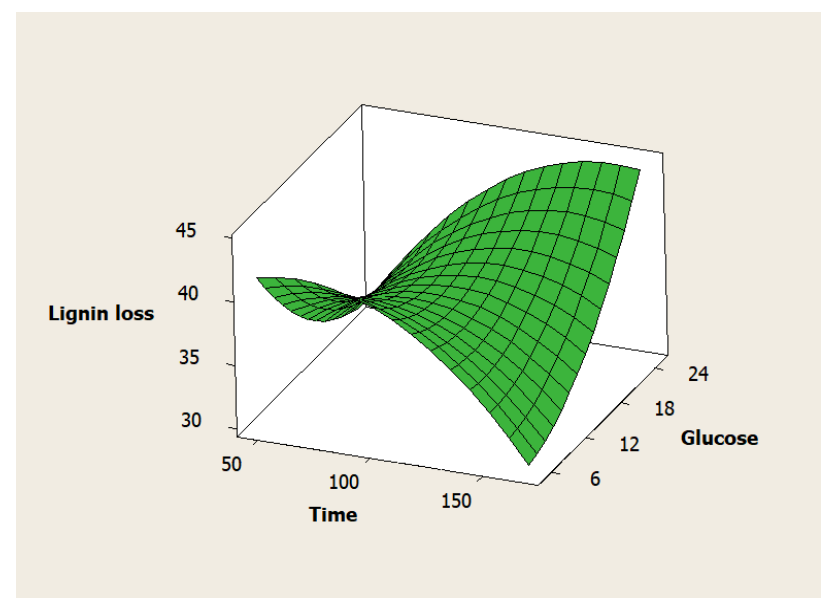

Figure 2: Response surface plot for the interaction between incubation time and $1 \%$ glucose volume on lignin loss (hold values: temperature, $30^{\circ} \mathrm{C}$ ) 
Ashuvila Mohd Aripin et al., International Journal of Emerging Trends in Engineering Research, 8(1.2), 2020, 253- 263

Table 6: BBD matrix for delignification process of microbiome's bacteria from $R$. ferrugineus

\begin{tabular}{|c|c|c|c|c|c|c|}
\hline \multirow{2}{*}{ Run } & \multicolumn{3}{|c|}{ Experimental factors } & \multicolumn{2}{|c|}{ Response: Lignin loss, \% } & \multirow{2}{*}{$\begin{array}{c}\text { Error } \\
(\%)\end{array}$} \\
\hline & $\begin{array}{c}\text { Incubation } \\
\text { time, } h\end{array}$ & $\begin{array}{c}\text { Temperature } \\
{ }^{\circ} \mathbf{C}\end{array}$ & $\begin{array}{l}1 \% \text { glucose, } \\
\mathrm{mL}\end{array}$ & $\begin{array}{l}\text { Actual } \\
\text { value }\end{array}$ & $\begin{array}{l}\text { Predicted } \\
\text { value }\end{array}$ & \\
\hline 1 & 168 & 30 & 25 & 46.1 & 45.1 & 2.2 \\
\hline 2 & 108 & 30 & 15 & 38 & 37.6 & 3.3 \\
\hline 3 & 168 & 25 & 15 & 38 & 40.4 & -6.4 \\
\hline 4 & 168 & 30 & 5 & 29.7 & 31 & -4.5 \\
\hline 5 & 48 & 35 & 15 & 38.1 & 42.1 & -10.6 \\
\hline 6 & 108 & 25 & 5 & 31.1 & 27.6 & 11 \\
\hline 7 & 108 & 35 & 25 & 36 & 32 & 11.1 \\
\hline 8 & 168 & 35 & 15 & 30.4 & 35.7 & -17.3 \\
\hline 9 & 108 & 30 & 15 & 38 & 37.6 & 3.3 \\
\hline 10 & 48 & 25 & 15 & 31.2 & 32.3 & -3.5 \\
\hline$* 11$ & 108 & 35 & 5 & 52.1 & 45.7 & 12.2 \\
\hline 12 & 108 & 30 & 15 & 38 & 37.6 & 3.3 \\
\hline 13 & 48 & 30 & 5 & 39.8 & 42.4 & -6.6 \\
\hline 14 & 48 & 30 & 25 & 31.8 & 32.1 & -0.9 \\
\hline 15 & 108 & 25 & 25 & 46.2 & 45.1 & 2.4 \\
\hline
\end{tabular}

Table 7: ANOVA for the response surface quadratic model

\begin{tabular}{|l|c|c|c|c|c|c|}
\hline \multicolumn{1}{|c|}{ Source } & $\begin{array}{c}\text { Sum of } \\
\text { squares }\end{array}$ & $\mathbf{D F}$ & $\begin{array}{c}\text { Means } \\
\text { square }\end{array}$ & $\boldsymbol{F}$ value & $\boldsymbol{p}$ value & Remarks \\
\hline Model & 1689.32 & 9 & 187.702 & 58.03 & 0 & Significant \\
\hline $\mathrm{A}$ & 4.08 & 1 & 4.084 & 1.26 & 0.269 & \\
\hline $\mathrm{B}$ & 37.75 & 1 & 37.75 & 11.67 & 0.002 & Significant \\
\hline $\mathrm{C}$ & 21.28 & 1 & 21.282 & 6.58 & 0.015 & Significant \\
\hline $\mathrm{A}^{2}$ & 205.77 & 1 & 181.689 & 56.17 & 0 & Significant \\
\hline $\mathrm{B}^{2}$ & 0.59 & 1 & 2.243 & 0.69 & 0.411 & \\
\hline $\mathrm{C}^{2}$ & 90.5 & 1 & 90.499 & 27.98 & 0 & Significant \\
\hline $\mathrm{AB}$ & 155.52 & 1 & 155.52 & 48.08 & 0 & Significant \\
\hline $\mathrm{AC}$ & 445.3 & 1 & 445.301 & 137.67 & 0 & Significant \\
\hline $\mathrm{BC}$ & 728.52 & 1 & 728.521 & 225.23 & 0 & Significant \\
\hline $\begin{array}{l}\text { Residual } \\
\text { error }\end{array}$ & 113.21 & 35 & 3.235 & & & \\
\hline Lack of fit & 92.7 & 3 & 30.9 & 48.22 & 0 & Significant \\
\hline Pure error & 20.51 & 32 & 0.641 & & & \\
\hline Total & 1802.53 & 44 & & & & \\
\hline
\end{tabular}

$\mathrm{A}=$ Incubation time, $\mathrm{B}=$ Temperature, $\mathrm{C}=1 \%$ glucose, $\mathrm{DF}=$ degree of freedom, $f=$ Fisher's function, $p=$ corresponding level of significance $(p<0.05)$ 


\subsection{Temperature vs. 1\% Glucose Volume}

Figure 3 presents a response surface plot of temperature against $1 \%$ glucose volume at fixed level of time $(108 \mathrm{~h})$. As shown in Figure 3, the lignin loss increased at low temperature $\left(25^{\circ} \mathrm{C}\right)$ and increased at high $1 \%$ glucose volume $(25 \mathrm{~mL})$. In contrast, lignin loss decreased at low temperature and low volume of $1 \%$ glucose. This similar with interaction at high temperature and high volume of $1 \%$ glucose.

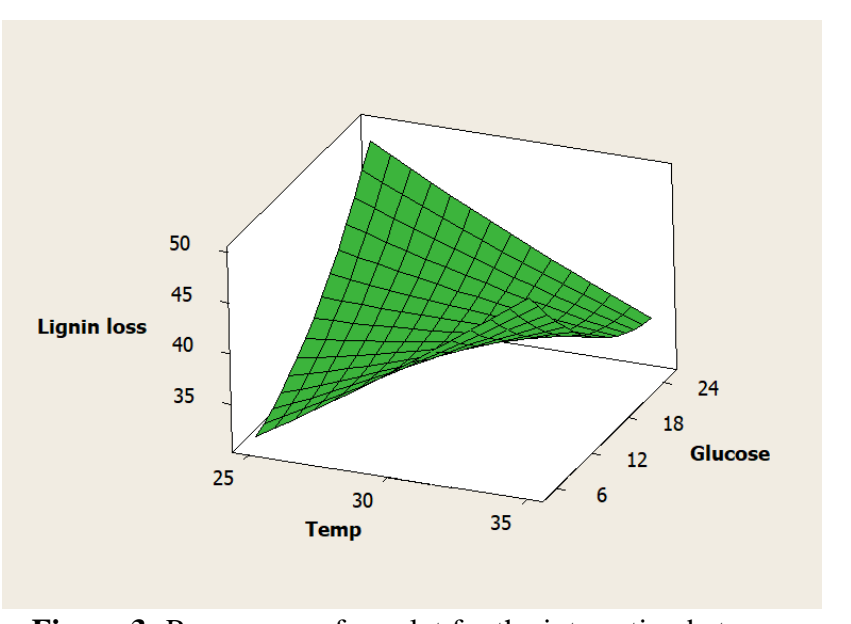

Figure 3: Response surface plot for the interaction between temperature and $1 \%$ glucose volume on lignin loss (hold values: time, $108 \mathrm{~h}$ )

\subsection{Optimization Conditions}

From the response surface plots, it can be observed that each of the three variables used has its own individual effects on lignin loss by Rhynchophorus ferrugineus microbiome's enzymes in bio-delignification process. From the BBD analysis, the optimal values were obtained $48 \mathrm{~h}$ for incubation time at $35^{\circ} \mathrm{C}$ of temperature with added $5 \mathrm{~mL}$ of $1 \%$ glucose volume. At these optimal conditions, the predicted lignin loss of biodelignification process was $54.68 \%$.

\subsection{Mechanical Properties of Handsheet}

The mechanical properties (also known as strength properties) of handsheets can serve as indicator to determine the characteristic of handsheet product from non-wood or wood resource involved in the paper-making industry. Monitoring of mechanical properties of handsheet was carried out to evaluate the effectiveness of delignification process of OPEFB fibers. In this study, the mechanical properties of OPEFB handsheet were focused on the tensile strength, tearing resistance and bursting strength. Handsheet with higher values in mechanical properties could be selected as alternative pulping process in pulp and paper industry. Therefore, the test on mechanical properties is conducted on handsheets from untreated and treated OPEFB. The treated sample is the sample produced after delignification process at optimization condition.
Figure 4 shows the value of tensile index of handsheet for untreated and treated OPEFB. The highest value of tensile index was obtained in treated OPEFB $(9.93 \mathrm{Nm} / \mathrm{g})$ under biodelignification process compared to untreated OPEFB $(9.18 \mathrm{Nm} / \mathrm{g})$. The error bars are small indicating good accuracy and precision of repeatability results in this study. The high value of tensile index in treated OPEFB was proven that the biodelignification process is comparable for pulp and paper-based industry.

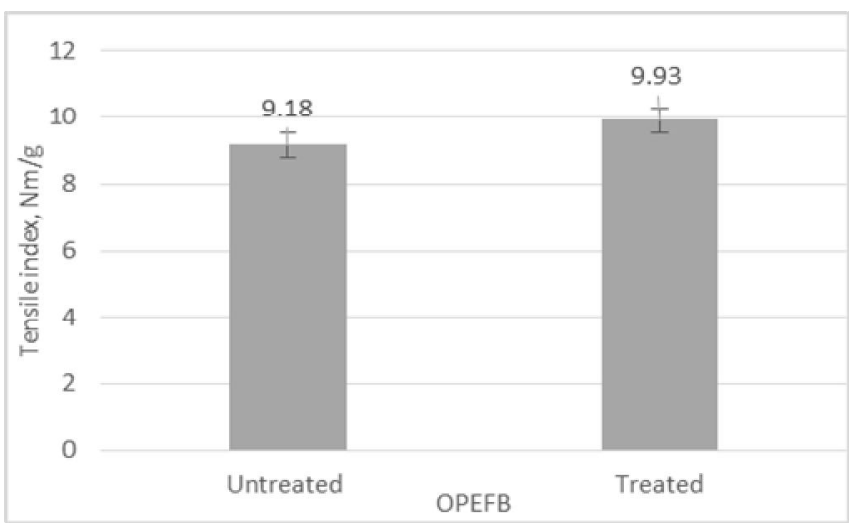

Figure 4: Tensile index of handsheet for untreated and treated OPEFB

In pulp and paper industry, tensile strength is one of the important mechanical parameter in describing the resistance of the paper product [32]. The tensile strength is also an indicator to fiber strength, fiber bonding and fiber length of material [33]. In addition, increase of tensile index also depends on the contact area of inter fiber bonding [33]. Table 9 presents the comparison tensile index of OPEFB with other published materials. OPEFB shows the low tensile index (9.93 Nm/g) compared to poplar wood $(42.70 \mathrm{Nm} / \mathrm{g})$, which OPEFB have low cellulose content than poplar wood that affects the strength and contact area of fiber interbonding [24], [34]. Interestingly, when comparing to other published material, it is significantly higher than vine straw and giant reed node (Table 9) which has been successfully applied in pulp and paper-based industry.

Table 9: Comparison of tensile index value of OPEFB and other non-wood and wood plants species

\begin{tabular}{|l|c|c|}
\hline Materials & $\begin{array}{c}\text { Tensile index, } \\
\mathbf{N m} / \mathbf{g}\end{array}$ & References \\
\hline OPEFB & 9.93 & This study \\
\hline Vine straw & 6.45 & {$[35]$} \\
\hline $\begin{array}{l}\text { Giant reed } \\
\text { node }\end{array}$ & 5.2 & {$[36]$} \\
\hline Hardwood & $45-54$ & {$[37]$} \\
\hline
\end{tabular}

Figure 5 shows the value of tear index of handsheet for untreated and treated OPEFB at optimum condition. When comparing between untreated $\left(2.52 \mathrm{mN} . \mathrm{m}^{2} / \mathrm{g}\right)$ and treated 
$\left(2.57 \mathrm{mN} . \mathrm{m}^{2} / \mathrm{g}\right)$ OPEFB, it appears that tear index are relatively close. Normally, tear index decreases with increasing proportion of fiber length in material [38]. Fiserova and Gigac [34] stated that less interbonding may be correlated with the decreasing number of bonds (hydrogen bonds) formed by the material of hemicellulose. From this study, the tear index of untreated and treated OPEFB are quite similar due to the hemicellulose content is not significant difference after biodelignification process.

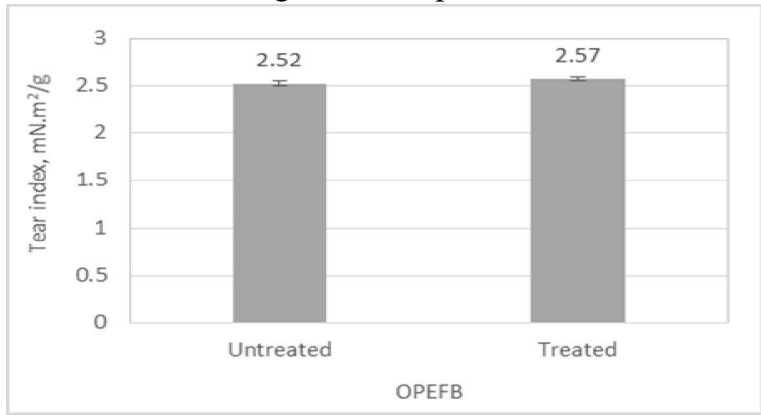

Figure 5: Tear index of handsheet for untreated and treated OPEFB

Table 10 presents the difference of tear index obtained in OPEFB and other published non-wood and hardwood plants. Interestingly, OPEFB has the highest tear index than non-wood and hardwood plants (Table 10). This is due to the high fiber bonding as indicated high hemicellulose content and low lignin content of material [33].

Table 10: Comparison of tear index value of OPEFB and other

\begin{tabular}{|c|c|c|}
\hline Materials & $\begin{array}{c}\text { Tear index, } \\
\text { mN.m²/g }\end{array}$ & References \\
\hline OPEFB & 2.57 & This study \\
\hline Vine straw & 0.9 & [35] \\
\hline Rice straw & 1.2 & [27] \\
\hline $\begin{array}{l}\text { Cogon } \\
\text { grass }\end{array}$ & 2.17 & [23] \\
\hline Hardwood & 1.09 & [39] \\
\hline
\end{tabular}

Figure 6 illustrates the comparison burst index between untreated and treated OPEFB. The treated OPEFB shown the high burst index $\left(0.98 \mathrm{kPa} \cdot \mathrm{m}^{2} / \mathrm{g}\right)$. This was shown successfully the biodelignification process by Rhynchophorus ferrugineus microbiome's enzymes on OPEFB under optimum condition.

Table 11 reported that the burst index obtained from OPEFB compared to other published nonwood and hardwood plants. Although OPEFB has low burst index than vine straw, rice straw and hardwood, however, it has the high burst index than published oil palm leaves (Table 11) that have been successfully used in pulp and paper industry.

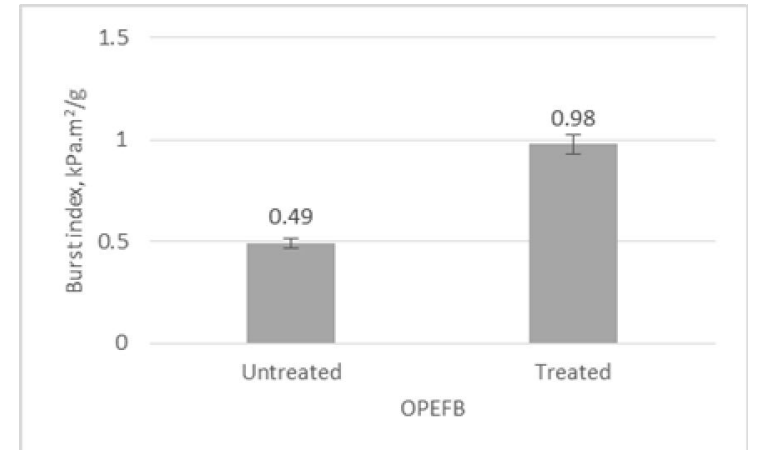

Figure 6: Burst index of handsheet for untreated and treated OPEFB

Table 11: Comparison of burst index value of OPEFB and other non-wood and wood plants species

\begin{tabular}{|l|c|c|}
\hline \multicolumn{1}{|c|}{ Materials } & $\begin{array}{c}\text { Burst index, } \\
\mathbf{k P a} . \mathbf{m}^{2} / \mathbf{g}\end{array}$ & References \\
\hline OPEFB & 0.98 & This study \\
\hline Vine straw & 1.01 & {$[35]$} \\
\hline Rice straw & 1.2 & {$[27]$} \\
\hline Oil palm leaf & 0.95 & {$[40]$} \\
\hline Hardwood & 1.4 & {$[41]$} \\
\hline
\end{tabular}

\section{CONCLUSIONS}

The purpose of this research is to determine the best condition of delignification process as an alternative process in pulp and paper-based industry, which focuses on the lignin loss of the OPEFB. The characterization of chemical properties of OPEFB fiber prior to treatment and after treatment was carried out successfully. The chemical properties of OPEFB at the best conditions by BBD such as cellulose content (47.98\%), hemicellulose (31.62\%), lignin content (12.35\%), extractive content $(1.85 \%)$ and ash content $(1.65 \%)$ indicate OPEFB fibre is a biomass for pulp and paper-based product.

Next, the optimization of bioprocessing conditions of $R$. ferrugineus microbiome's enzymes on OPEFB was elicited in the experimental design. Based on the $\mathrm{BBD}$, the experimental value shows the higher lignin loss is $52 \%$ at $35{ }^{\circ} \mathrm{C}$ temperature for $108 \mathrm{~h}$ incubation time in $5 \mathrm{~mL}$ of $1 \%$ glucose. The model was evaluated for selecting the optimal conditions and their respective levels. The final optimized biodelignification process conditions obtained from BBD is $54.68 \%$ of lignin loss at $35^{\circ} \mathrm{C}$ temperature for $48 \mathrm{~h}$ incubation time in $5 \mathrm{~mL}$ of $1 \%$ glucose.

Based on the mechanical properties, the overall handsheet produced by treated OPEFB fiber yield better quality pulp compared to untreated OPEFB fiber, but still low compare to hardwood plants resources. The mechanical properties values of treated OPEFB fibre with optimum delignification process 
are tensile index $(9.93 \mathrm{mN} / \mathrm{g})$, tearing index $(2.57 \mathrm{mN} \cdot \mathrm{m} 2 / \mathrm{g})$ and burst index $(0.98 \mathrm{kPa} . \mathrm{m} 2 / \mathrm{g})$.

The results of this study provide an understanding on feasibility of biodelignification process by $R$. ferrugineus microbiome's enzymes on OPEFB. The statistical optimization method helped to define the most critical operational variables and optimum rates led to the highest loss of lignin. In addition, it also offers a better alternative pulping process than using fungal and conventional mechanical and chemical treatments in pulp and paper-based industry. This biodelignification is expected to provide a cleaner technology.

\section{ACKNOWLEDGEMENT}

The authors acknowledge the help from Ministry of Education Malaysia for funding the financial support of this study through the medium of Fundamental Research Grant Scheme Vot No. FRGS/1/2018/TK03/UTHM/03/10. This study is partially sponsored by Universiti Tun Hussein Onn Malaysia (UTHM).

\section{REFERENCES}

1. O. Hassan, T. P. Ling, M. Y. Maskat, R. M. Illias, K. Badri, J. Jahim, and N. M. Mahadi. Optimization of pretreatments for the hydrolysis of oil palm empty fruit bunch fiber (EFBF) using enzyme mixtures. Biomass and Bioenergy, Vol. 56, pp 137-146, 2013.

2. M. B. A. Rahman, Z. I. Ishak, D. K. Abdullah, A. M. A Aziz, M. I. Basri, and A. B. Salleh. Swelling and dissolution of oil palm biomass in ionic liquids. Journal of Oil Palm Research, pp 1267-1276, 2012.

3. S. V. Menon and T. V. Ramana Rao. Nutritional quality of muskmelon fruit as revealed by its biochemical properties during different rates of ripening. International Food Research Journal, Vol. 19 No. 4, pp 1621-1628, 2012.

4. V. B. Agbor, N. Cicek, R. Sparling, A. Berlin, and D. B. Levin. Biomass pretreatment: Fundamentals toward application. Biotechnology Advances, Vol. 29 No. 6, pp 675-685, 2011.

5. C. Wan, and Y. Li. Fungal pretreatment of lignocellulosic biomass. Biotechnology Advances, Vol. 30 No. 6, pp 1447-1457, 2012.

6. L. Tabil, P. Adapa, and M. Kashaninejad. Biomass feed-stock pre-processing part 1: Pre-treatment, in Biofuel's Engineering Process Technology, M. A. D. S. Bernardes, Ed. United Kingdom: IntechOpen, 2011, pp. 411-438.

7. Z. Anwar, M. Gulfraz, and M. Irshad. Agro-industrial lignocellulosic biomass a key to unlock the future bio-energy: A brief review. Journal of Radiation Research and Applied Sciences, Vol. 7, No. 2, pp 163-173, 2014.
8. A. Husaini, F. A. Fisol, L. C. Yun, M. Hasnain, S. Muid, and H. A. Roslan. Lignocellulolytic enzymes produced by tropical white rot fungi during biopulping of Acacia mangium wood chips. Journal of Biochemistry Technology,Vol. 3 No.2, pp 245-250, 2011.

9. A. S. M. Kassim, N. Ishak, A. M. Aripin and D. N. F. A. Zaidel. Potential lignin degraders isolated from the gut of Rhynchophorus Ferrugineus. Advance of Engineering Research, (International Conference on Mechanics, Materials and Structural Engineering (ICMMSE), 66-72, $2016 \mathrm{a}$.

10. D. Prasetya, W. P. Panjiarto and F. E. Soetaredjo. Bio-Delignification Of Oil Palm Empty Fruit Bunch Of Using Trichoderma Viride And Escherichia Coli, Vol. 13, No. 2, pp 529-535, 2018.

11. A. Mohd Aripin, A. S. Mohd Kassim, N. H. Mat Nayan, S. M. Sharifah, F. Ayeronfe, M. H. Zainulabidin and N. Ishak. Optimisation of lignin degradation using co-culture bacterial gut species for ligninolytic enzyme production and lignin removal. Proceeding of $5^{\text {th }}$ International Conference on the Application of Science and Mathematics (SCIEMATHIC2019), 14 ${ }^{\text {th }}-$ $15^{\text {th }}$ August 2019, Melacca, Malaysia, 2019.

12. T $264 \mathrm{~cm}-07$. Preparation of wood for chemical analysis, 2007.

13. J. S. Han and J. S. Rowell. Chemical Composition of Fibers. Cellulose, Vol. 283, pp 83-134, 1997.

14. N. Cordeiro, M. N. Belgacem, I. C. Torres, and J. C. V. P. Moura. Chemical composition and pulping of banana pseudo-stems. Industrial Crops and Products, Vol. 19, No. 2, pp 147-154, 2004.

15. T $222 \mathrm{om}-02$. Acid-insoluble lignin in wood and pulp, 2000.

16. $\mathrm{T} 211$ om-02. Ash in wood, pulp, paper and paperboard: combustion at $525^{\circ} \mathrm{C}, 2002$.

17. T $205 \mathrm{sp}-02$. Forming handsheets for physical tests of pulp, 2002.

18. T $220 \mathrm{sp}-01$. Physical testing of pulp handshets, 2002.

19. T 494 om-06. Tensile properties of paper and paperboard (using constant rate of elongation apparatus), 2006.

20. T $414 \mathrm{om}-04$. Internal tearing resistance of paper (Elmendorf-type method), 2004.

21. T 403 om-08. Bursting strength of paper, 2010.

22. R. M. Rowell, J. S. Han, and J. S. Rowell,. Characterization and factors effecting fiber properties. In: Frollini E, Leão A L. \& Mattoso L H C (Eds.). Natural Polymers and Agrofibers Composites. Brazil: Embrape Agricultural Instrumentation, pp. 115-134, 2000.

23. A. S. M. Kassim, A. M. Aripin, N. Ishak, N. H. H. Hairon, N. A. Fauzi, N. F. Razali, and M. H. Zainulabidin. Potential of cogon grass (Imperata cylindrica) as an alternative fibre in paper-based industry. ARPN Journal of Engineering and Applied Sciences, Vol. 11 No. 4, pp 2681-2686, $2016 \mathrm{~b}$. 
24. N. Bidin, M. H. Zakaria, J. S. Bujang, and N. A. Abdul Aziz. Sustability of aquatic plants fibers for handmade papermaking. International Journal of Polymer Science, pp 1-9, 2015.

25. A. A. Mossello, J. Harun, H. Resalati, R. Ibrahim, S. R. F. Shmas and P. M.Tahir (2010). New approach to use of kenaf for paper and paperboard production. BioResources, Vol. 5, No. 4, pp 2112-2122, 2010.

26. A. A. Enayati, Y. Hamzeh, S. A. Mirshokraie and M. Molaii. Papermaking potential of canola stalk. BioResources, Vol. 4, No. 1, pp 245-256, 2009.

27. A. Rodríguez, A. Moral, L. Serrano, J. Labidi, and L. Jiméne. Rice straw pulp obtained using various methods. Bioresources Technology, Vol. 99, pp 2881-2886, 2008.

28. A. Tutus, N. Comlekcioglu, S. Karaman, and M. H. Alma. Chemical composition and fiber properties of Crambe orientalis and C. tataria. International Journal of Agriculture and Biology, Vol. 12, pp 286-290, 2010.

29. A. Tutus, Y. Kazaskeroğlu, and M. Çiçekler. Evaluation of tea wastes in usage pulp and paper production. BioResources, Vol. 10, No. 3, pp 5407-5416, 2015.

30. S. G. Dutta, A. B. Shaik, C. G. Kumar, and A. Kamal. Statistical optimization of production conditions of $\beta$-glucosidase from Bacillus stratospheric strain SG9. 3 Biotechnology, Vol. 7, No. 221, pp 1-13, 2017.

31. S. K. Kale, V. B. Patil, and A. G. Deshmukh. Statistical optimization of medium for laccase production by Rigidoporus sp. DK4. An International Quarterly Journal of Life Sciences, Vol. 11, No. 2, pp 915-920, 2016.

32. H. Goyal. Properties of paper. Retrieved on April 4, 2018, from http://www.paperonweb.com/Malaysia.html, 2010.

33. N. S. Abd Rahman and B. Azahari. Effect of calciul hydroxide filler loading on the properties of banana stem handsheets. BioResources, Vol. 7, No.3, pp 4321 4340, 2012.

34. M. Fišerová and J. Gigac, J. Comparison of hardwood kraft pulp fibre characteristics and tensile strength. Cellulose Chemistry and Technology, Vol. 45, No. 9-10, pp 627-631, 2011.

35. L. Jiménez, V. Angulo, E. Ramos, M. J. D. L. Torre, and J. L. Ferrer. Comparison of various pulping processes for producing pulp from vine shoots. Industrial Crops and Product, Vol. 23, No. 2, pp 122-130, 2006.

36. A. A. Shatalov, and H. Pereira, H. Papermaking fibers from giant reed (Arundodonax L.) by advanced ecologically friendly pulping and bleaching technologies. BioResources, Vol. 1, No. 1, pp 45-61, 2006.

37. D. Dutt and C. H. Tyagi. Comparison of various eucalyptus species for their morphological, chemical, pulp and paper making characteristics. Indian Journal of Chemical Technology, Vol. 18, pp 145-151, 2011
38. A. Ashori, J. Harum, M. N. M. Yusoff, W. D. Wanrosli, W. M. Z. Wanyunus and K. Z. M. Dahlan. TCF bleaching of kenaf (Hibiscus cannabinus) pulp for papermaking applications. Journal of Tropical Forest Science, Vol. 16, No. 4, pp 463-471, 2004.

39. F. López, J. Ariza, I. Pérez, and L. Jiménez. Comparative study of paper sheets from olive tree wood pulp obtained by soda, sulphite or kraft pulping. Bioresources Technology, Vol. 71, pp 83-86, 2000

40. A. S. M. Kassim, A. M. Aripin, N. Ishak, M. H. Zainulabidin and D. N. F. A. Zaidel. Oil palm leaf fibre and its suitability for paper-based products. ARPN Journal of Engineering and Applied Science, Vol. 11, No. 11, pp 7364-7369, 2016c.

41. P. Khristova, O. Kordsachia, R. Patt, I. Karar, and T. Khider. Environmentally friendly pulping and bleaching of bagasse. Industrial Crops and Products, Vol. 23, pp 131-139, 2005 